\title{
Effects of Monensin on the Immunocytochemical Detection of Matrix Metalloproteinase 3 in Human Periodontal Ligament Cells
}

\author{
Hiroshi Nakaya, Kyuichi Kamoi \\ Ann M. Tran* and David L. Cochran* \\ Department of Periodontology, The Nippon Dental University, School of Dentistry at Tokyo \\ 2-3-16 Fujimi, Chiyoda-ku, Tokyo 102, Japan \\ (Chief : Prof. Kyuichi Kamoi) \\ *Department of Periodontics, University of Texas Health Science Center at San Antonio \\ (Chief : Prof. David L. Cochran) \\ (Accepted for publication: November 9, 1995)
}

\begin{abstract}
The matrix metalloproteinases are thought to play an important role in the destruction of connective tissue in periodontal disease. The monovalent ionophore, monensin, has been used in a procedure to immunolocalize metalloproteinases in cultured fibroblasts. Specifically this study investigated the effects of monensin on the immunocytochemistry of matrix metalloproteinase 3 (MMP-3) by comparing immunolocalization and gene expression in human periodontal ligament (PDL) cells. Cultured PDL cells were treated with and without IL-1 $\beta(1000 \mathrm{pg} / \mathrm{m} l)$ for 24 hours. Monensin (5 $\mathrm{mM}$ ) was added to half the PDL cells for the last 3 hours of the incubation period. Immunolocalization of MMP-3 was performed by the avidin-biotin
\end{abstract}

-peroxidase complex method. Gene expression of MMP-3 was investigated by the reverse transcriptase polymerase chain reaction (RT-PCR). Immunolocalization of MMP-3 in PDL cells was not observed when cells were not treated with monensin, even when treated with IL-1 $\beta$. According to the results of RT-PCR, monensin did not alter MMP-3 gene expression stimulated with IL-1 $\beta$. The numbers of MMP-3 producing cells and the amount of MMP-3 mRNA present did not conflict. Our Findings suggest that monensin treatment of PDL cells is an effective method of immunocytochemically visualizing MMP-3 without affecting MMP-3 message synthesis.

Key words: MMP-3, Monensin, Immunocytochemistry, RT-PCR

要旨：マトリックス・メタロプロテナーゼは歯周疾患における組織破壊に重要な役割をはたしている。モネン シンは, 培養線維芽細胞におけるメタロプロテナーゼの局在を免疫細胞化学的に検索するために用いられてい る。本研究は, マトリックス・メタロプロテナーゼ 3 (MMP-3) を免疫細胞化学的に観察するために用いられる モネンシンの影響を検証することを目的として，上卜歯根膜由来の細胞における MMP-3 の局在とその mRNA 発現とを比較検討した。歯根膜由来の細胞に IL-1 $\beta$ を 24 時間，さらに $5 \mathrm{mM}$ のモネンシンを 3 時間作用させ た。MMP-3 の局在は, 酵素抗体法にて観察した。MMP-3 mRNA の発現は, RT-PCR 法を用い定量した。歯 根膜由来の細胞に扔ける MMP-3 の局在は，モネンシンを作用させないときは，IL-1 $\beta$ を作用させたとしても 観察されなかった。一方, MMP-3 mRNA の発現には, モネンシンによる影響はなかった。 MMP-3 陽性細胞 数と MMP-3 mRNA 発現量とは, 相反するものではなかった。以上の結果より, モネンシン処理は, MMP-3 mRNA 発現に影響を及ぼすことなく, 免疫細胞化学的に MMP-3 を観察するための有効な方法であることが示 唆された。

索引用語：MMP-3, モネンシン, 免疫細胞化学, RT-PCR 


\section{Introduction}

Matrix metalloproteinase 3 (MMP-3) degrades a wide range of substrates in extracellular matrices, including fibronectin, type IV collagen, laminin, and proteoglycan ${ }^{1,2)}$. In addition, MMP-3 is essential for full activation of procollagenase ${ }^{3)}$. Thus MMP -3 is considered to play an important role in the destruction of connective tissue in periodontal disease ${ }^{4,5}$.

Some investigators have examined gingival fibroblasts and gingival biopsies immunocytochemically to establish the relationship between periodontal disease and MMP- $3^{6}$. After MMP-3 is synthesized, it is rapidly secreted from cells without intracellular storage. The monovalent ionophore monensin has been used in these procedures to immunolocalize $\mathrm{MMPs}^{6 \sim 9)}$. Monensin treatment interferes with intercellular transport of newly synthesized secretory proteins, proteoglycans and plasma membrane glycoproteins ${ }^{10,11)}$. It is unclear, however, whether monensin affects MMP-3 production. In this study we investigated the effect of utilization of monensin for immunocytochemistry of MMP-3 by comparing immunolocalization and gene expression in human periodontal ligament (PDL) cells.

\section{Materials and Methods}

\section{Cell culture}

PDL cells were derived from freshly extracted teeth removed for orthodontic expediency with no periodontal reason. The cells were maintained in Dulbecco's Modified Eagle's medium (DMEM) (Gibco BRL, Grand Island, NY) supplemented with $10 \%$ fetal calf serum in $37^{\circ} \mathrm{C}$ humidified air with $5 \%$ $\mathrm{CO}_{2}$.

PDL cells from the 4 th to 10 th passage were treated with IL $1-\beta(1000 \mathrm{pg} / \mathrm{m} l)$ (R \& D systems, Minneapolis, MN) and compared to the untreated control. The cells were incubated for 24 hours in DMEM with $0.1 \%$ fetal calf serum. Monensin (5 $\mathrm{mM}$ ) (Sigma, St. Louis, MO) was added to half the PDL cell cultures for the last 3 hours of the incubation period.

\section{Immunocytochemical method}

PDL cells grown on glass coverslips were fixed in $4 \%$ paraformaldehyde for 10 minutes and rinsed with PBS. The cells were then permeabilized with $0.1 \%$ Triton $\mathrm{X}-100$ for 10 minutes, and endogenous peroxidases were quenched with $0.3 \% \quad \mathrm{H}_{2} \mathrm{O}_{2}$ in methanol for $30 \mathrm{~min}$. After washing with $\mathrm{PBS}$ and incubation in $1.5 \%$ normal rabbit serum (Vectastain Elite ABC : Vector Laboratories, Burlingame, CA) for 20 minutes to reduce nonspecific binding, the cells were incubated overnight at $4^{\circ} \mathrm{C}$ with sheep anti-MMP-3 IgG at dilution of $1: 500$ (The Binding Site, San Diego, CA). The cells were then washed for 30 minutes with PBS and treated with biotinylated anti-sheep IgG (Vectastain Elite $\mathrm{ABC}$ : Vector Laboratories, Burlingame, CA). Following PBS washing, avidin-biotin-peroxidase complex (Vectastain Elite ABC: Vector Laboratories, Burlingame, $\mathrm{CA}$ ) was added and incubation was performed for an additional 30 minutes. After washing with PBS, the cells were incubated in peroxidase substrate solution (DAB Substrate Kit for Horseradish Peroxidase : Vector Laboratories, Burlingame, CA) for development of the avidin -biotin-peroxidase complex and rinsed with tap water. The cells were then counterstained with methyl green, dehydrated in absolute alcohol, immersed in xylene, and mounted.

3. Measurement of MMP-3 mRNA levels by the reverse transcriptase-polymerase chain reaction (RT-PCR)

Total RNA was isolated by a modified procedure described by Chmozynski and Sacchi ${ }^{12}$. Aldolase (internal control) and MMP-3 mRNA levels were determined by RT-PCR, as previously described 13,14). The sequence of the PCR primers for aldolase was 5'-TCATCCTCTTCCATGAGACACTCTA-3' (sense primer) and 5'ATTCTGCTGGCAGATACTGGCATAA-3' (anti-sense primer). The sequence of the PCR primers for MMP- 3 was 5'-AGATGCTGTTGATTCTGCTGTTGAG-3' (sense primer) and 5'-ACAGCATCAAAGGACAAAGCAGGAT-3' (anti-sense primer). The primers yielded a 314 base-pair PCR product for aldolase and a 516 base pair product for MMP -3. Following RT-PCR, using ${ }^{32} \mathrm{P}-$ end labeled primer, was visualized by ethidium bromide staining 
and excised from the 5\% polyacrylamide electrophoresis gel. Radioactivity was determined by scintillation counting.

\section{Results}

PDL cells grown on coverslips were stained by the $\mathrm{ABC}$ method using anti-MMP-3 IgG. Few MMP-3 positive cells were observed when treated with monensin alone (Fig. 1. a). When PDL cells were treated with $\mathrm{IL}-1 \beta$ puls $5 \mathrm{mM}$ monensin, MMP-3- positive vesicles were visible in many cells (Fig. 1. b). This demonstrated that MMP-3 synthesis could be induced in these cells. MMP-3 was not visible in cells not treated with monensin (Fig. 1. c). Few PDL cells treated with IL-1 $\beta$ without
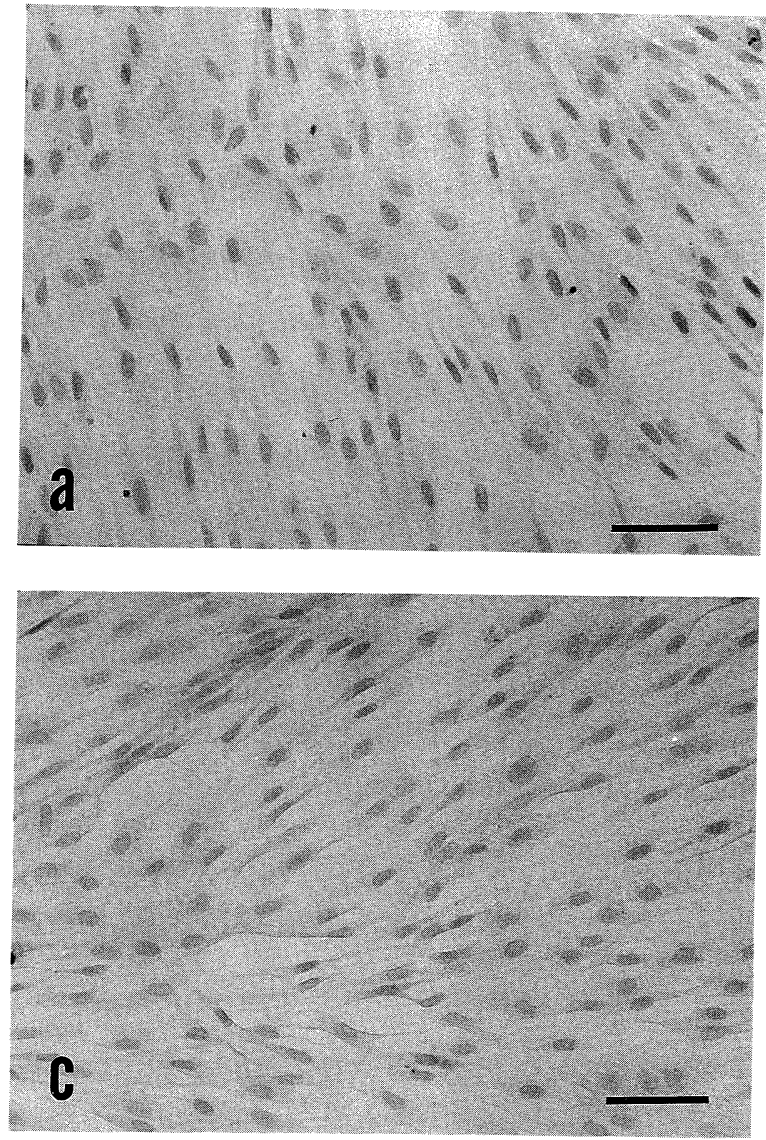

Fig. 1 Immunolocalization of MMP-3 in human PDL cells.

(a) PDL cells were treated with monensin only.

(b) Cells were treated with IL-1 $\beta$ and monensin. MMP-3 positive vesicles were visible in many cells (Arrows).

(c) Cells were not treated with monensin.

(d) Cells were treated with IL-1 $\beta$ but without monensin. Bar : $50 \mu \mathrm{m}$.

monensin were positive (Fig. 1. d). mRNA synthesis (Fig. 2, 4).

\section{Discussion}
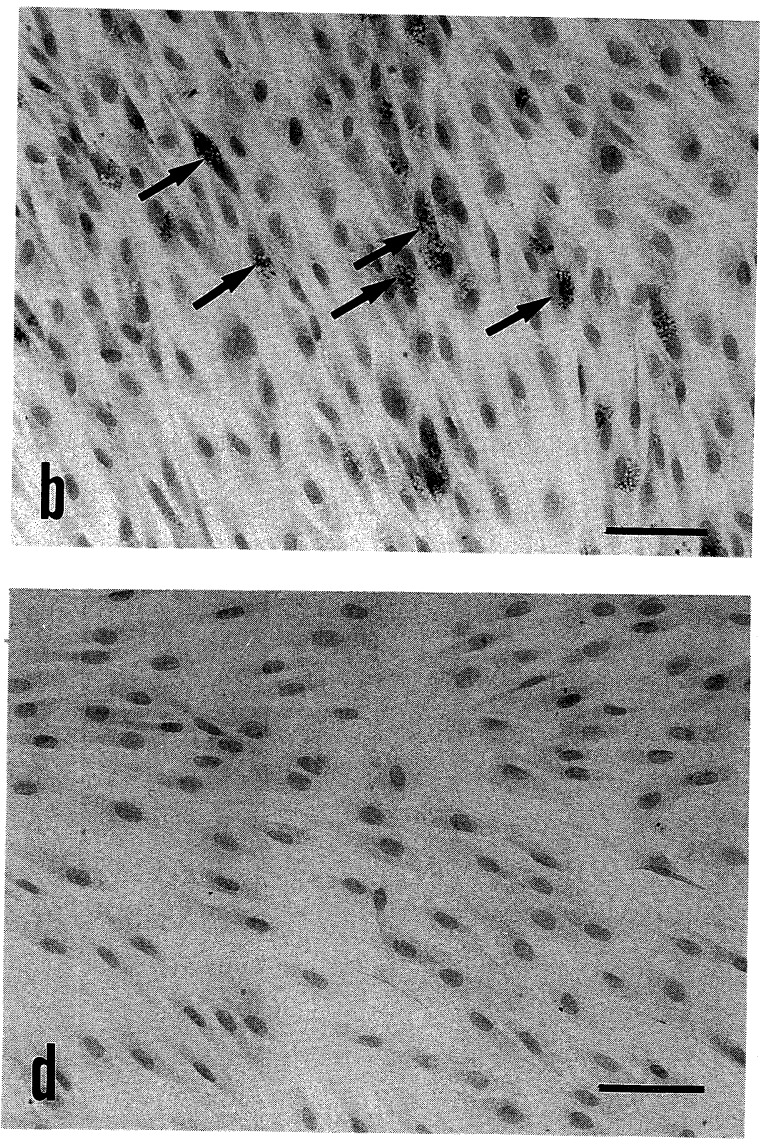

Aldolase mRNA levels after IL-1 $\beta$ treatment, monensin treatment, and $\mathrm{IL}-1 \beta$ puls monensin treatment were no different from the control (Fig. $2,3)$, and thus aldolase was used as an internal control for quantification. IL-1 $\beta$ treatment significantly upregulated the expression of $\mathrm{MMP}-3$ mRNA (Fig. 2). The addition of monensin to control or IL $-1 \beta$ treated cells had no effect on MMP-3

Metalloproteinases play a major role in tissue destruction of extracellular matrix macromolecules in periodontal diseases ${ }^{4,5)}$. These enzymes are pres- 


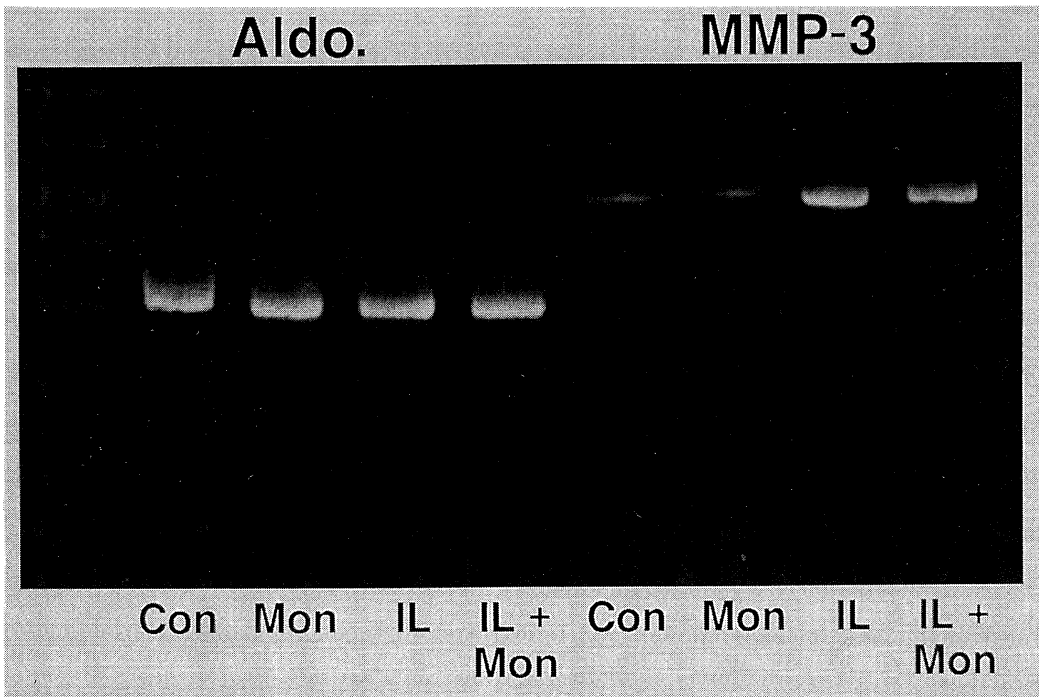

Fig. 2 RT-PCR products were separated with 5\% polyacrylamide gel electrophoresis and stained with ethidium bromide. Monensin did not alter MMP-3 gene expession which was stimulated in the presence of IL-1 $\beta$.

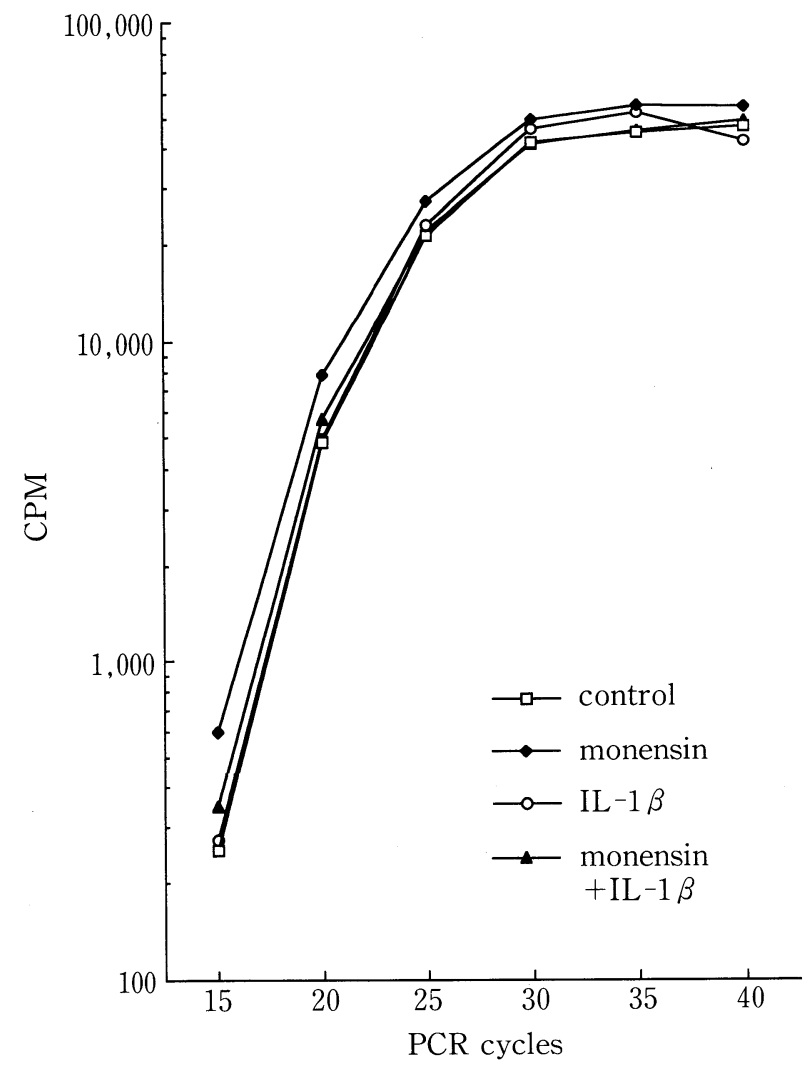

Fig. 3 Effect of IL-1 $\beta$ and/or monensin on aldolase mRNA. Aldolase mRNA levels were not change by monensin and/or IL-1 $\beta$ treatment.

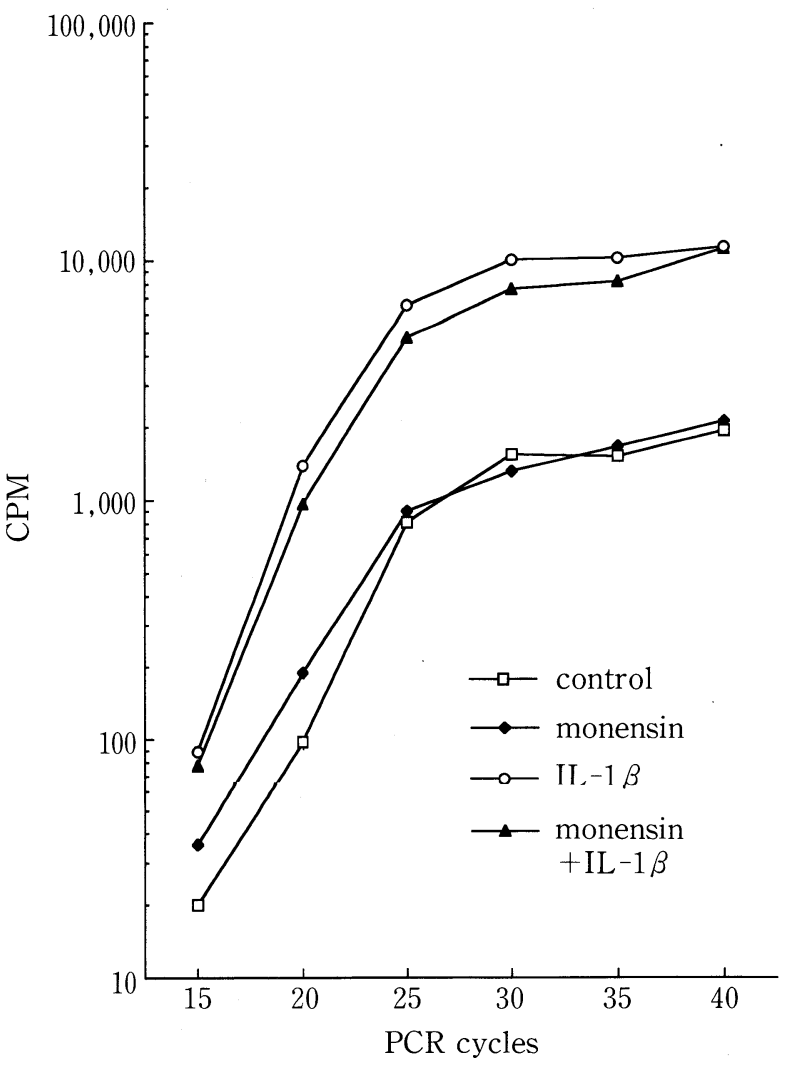

Fig. 4 Effect of IL-1 $\beta$ and/or monensin on MMP -3 mRNA. IL $-1 \beta$ treatment significantly upregulated the expression of $\mathrm{MMP}^{-3}$ mRNA. The addition of monensin to control or IL-1 $\beta$ treated cells had no effect on mRNA synthesis. 
ent in gingival crevicular fluid, saliva and periodontal tissues, as reported by many investigatrors ${ }^{15 \sim 16)}$. The characterization of metalloproteinases and their mechanism of production are the key to understanding their role in the pathogenesis of periodontal disease. Immunocytochemical methods are useful for assessing of the localization and production of metalloproteinases.

MMP-3 degrades a wide spectrum of extracellular matrix macromolecules, including proteoglycans, fibronection, type IV collagen and laminin $^{1,2)}$. Birkedal-Hansen ${ }^{4)}$ has suggested that MMP-3 may act as a marker for tissue degradation. MMPs and TIMPs are rapidly secreted after synthesis from cells without evidence of intercellular storage. Immunolocalization of MMPs in tissues and cultured cells was possible when the specimens were treated with the monovalent ionophore monensin. Monensin interferes with the processing and secretion of proteins from cells in culture, probably by blocking packaging by the Golgi apparatus ${ }^{10,11}$.

Cycloheximide inhibits protein synthesis and induces MMP- 3 mRNA, but not MMP- 1 mRNA ${ }^{18}$. The effect of monensin on MMP-3 accumulation in cells seems to be the opposite of cycloheximide. It has bees hypothesized that monensin downregulates MMP-3 mRNA expression. If this were true, monensin treatment to visualize MMP-3 would not be logical. Our results indicate that monensin treatment for immunocytochemical detection did not alter MMP-3 mRNA expression. Thus, monensin treatment in preparation for immunocytochemistry provides an effective method of determining the presence of MMP-3, and the results of MMP -3 protein synthesis do not conflict with mRNA expression indicative of increased protein synthesis.

\section{References}

1) Alexander, C.M. and Werb, Z. : Proteinases and extracellular matrix remodeling. Curr. Opin. Cell Biol., 1 : 974-982, 1989.

2) Okada, Y., Nagase, H. and Harris, E.D. Jr. : A metalloproteinase from human rheumatoid synovial fibroblasts that digests connective tissue matrix components. J. Biol. Chem. 261 : 14245-
14255, 1986.

3) Murphy, G., Cockett, M.I., Stephens, P.E., Smith, B.Y. and Docherty, A.J.P.: Stromelysin is an activator of procollagenase. Biochem. J. 248:265 -268, 1987.

4) Birkedal-Hansen $\mathrm{H}$ : Role of matrix metalloproteinases in human periodontal diseases. J. Periodontol. 64:474-484, 1993.

5) Alexander, M.B. and Damoulis, P.D., The role of cytokines in the pathogenesis of periodontal disease, Williams, R.C., Yukna, R.A., Newman, M.G., Current Opinion in Periodontolgy, Current Science Ltd, Philadelphia, 1994, 39-53.

6) Meikle, M.C., Hembry, R.M., Holley, J., Horton, C., McFarlane, C.G. and Reynolds, J.J. : Immunolocalization of matrix metalloproteinases and TIMP-1 (tissue inhibitor of metalloproteinaes) in human gingival tissues from periodontitis patients. J. Periodont. Res. 29 : 118-126, 1994.

7) Murphy, G., Hembry, R.M. and Reynolds, J.J. : Characterization of a specific antiserum to rabbit stromelysin and demonstration of the synthesis of collagenase and stromelysin by stimulated rabbit articular chondrocytes. Collagen Rel. Res. $6: 351$ $-364,1986$

8) Okada, Y., Takeuchi, N., Tomita, K., Nakanishi, I. and Nagase, H. : Immunolocalisation of matrix metalloproteinase 3 (stromelysin) in rheumatoid synovioblast (B cells) : correlation with rheumatoid arthritis. Ann. Rheum. Dis. $48: 645^{-}$ 653, 1989.

9) Salamonsen, L.A., Nagase, H. and Woolley, D. E. : Production of matrix metalloproteinase 3 (stromelysin) by cultured ovine endometrial cells. J. Cell Sci. 100:381-385, 1991.

10) Tartakoff, A.M. : Perturbation of vesicular traffic with the carboxylic ionophore monensin. Cell $32: 1026-1028,1983$.

11) Morré, D.J., Morré, D.M., Mollenhauser, H.H. and Reutter, W. : Golgi apparatus cisternae of monensin-treated cells accumulate in the cytoplasm of liver slices. Eur. J. Cell Biol. 43 : 235-242, 1987.

12) Chomczynski, P. and Scchi, N. : Single step method of RNA isolation by acid guanigium thiocynate-phenol-chloroform extraction. Anal. Biochem. 162 : 156-159, 1987.

13) Milam, S.B., Magnuson, V.L., Steffensen, B., Chen, D. and Klebe, R.J. : IL-1 $\beta$ and prostaglandins regulate integrin mRNA expression. J. Cell Physiol. 149: 173-183, 1991.

14) Alvares, O., Klebe, R., Grant, G. and Cochran, D. 
L. : Growth factor effects on the expression of collagenase and TIMP-1 in periodontal ligament cells. J. Periodontol. $66: 552-558,1995$.

15) Gangbar, S., Overall, C.M., McCulloch, C.A.G. and Sodek, J. : Identification of polymorphonuclear leukocyte collagenase and gelatinase activities in mouthrinse samples: Correlation with periodontal disease activity in adult and juvenile periodontitis. J. Periodont. Res. 25:257-267, 1990.

16) Overall, C.M., Sodek, J., McCulloch, C.A.G. and Birek, P. : Evidence for polymorphonuclear leukocyte collagenase and 92-kilodalton gelatinase in gingival crevicular fluid. Infect. Immun. 59 : 4687-4692, 1991.

17) Sorsa, T., Ingman, T., Suomalainen, K., Halinen, S., Saari, H., Konttinen, Y.T., Uitto, V-J. and Golub, L.M. : Cellular source and tetracyclineinhibition of gingival crevicular fluid collagenase of patients with labile diabetes mellitus. J. Clin. Periodontol. 19 : 146-149, 1992.

18) Otani, Y., Quinones, S., Saus, J., Kurkinen, M., Harris and, E.D. Jr. : Cycloheximide induces stromelysin mRNA in culutured human fibroblasts. Eur. J. Biochem. 192 : 75-79, 1990.

\section{連絡先：}

日本歯科大学歯学部歯周病学教室

₹ 102 東京都千代田区富士見 2-3-16 